\title{
Screening of Brazilian plants for the presence of peroxides
}

\author{
Eloir Pedro Schenkel ${ }^{*}$, Gerhard Rücker ${ }^{2}$, Detlef Manns², Miriam B. Falkenberg ${ }^{3}$, \\ Nelson I. Matzenbacher ${ }^{4}$, Marcos Sobral', Lilian A. Mentz ${ }^{4}$, Sérgio A.L. Bordignon ${ }^{5}$, \\ Berta M. Heinzmann ${ }^{6}$
}

\begin{abstract}
${ }^{1}$ Faculdade de Farmácia, Universidade Federal do Rio Grande do Sul, 2 Pharmazeutisches Institut, Universität Bonn, ${ }^{3}$ Departamento de Ciências Farmacêuticas, Universidade Federal de Santa Catarina, ${ }^{4}$ Departamento de Botânica, Universidade Federal do Rio Grande do Sul, ${ }^{5}$ Curso de Ciências Biológicas, Universidade Luterana do Brasil, ${ }^{6}$ Departamento de Farmácia Industrial, Universidade Federal de Santa Maria
\end{abstract}

*Correspondence:

E.P. Schenkel

Departamento de Ciências

Farmacêuticas

Centro de Ciências da Saúde

Universidade Federal de Santa

Catarina

Campus Universitário /Trindade

88.040-900 - Florianópolis-SC, Brasil

E-mail: schenkel@ccs.ufsc.br
Chloroform or dichloromethane extracts of 357 southern Brazilian plant species were tested for the presence of peroxides by thinlayer chromatography, using the spray reagent from Huber \& Fröhlke. From the species tested, 71 (20\%) showed positive results and most of them (56\%) are Asteraceae species. The species tested were mainly from Asteraceae, but 55 more families were screened, in a total of 77 genera surveyed.

\section{INTRODUCTION}

The occurrence of natural products which contain a peroxide group has been known since 1911, when ascaridole was isolated from the essential oil of Chenopodium ambrosioides (Chenopodiaceae). This oil was utilized as anthelmintic and ascaridole was identified as responsible for its activity (Gessner, 1953; Hope, 1958). In the following decades, compounds with a similar structure were not isolated; peroxides were considered to be too unstable and ascaridole was thought to be an exception.

In the meantime, as much as 320 peroxides have been isolated from natural material (Casteel, 1992). They occur mainly as terpene derivatives, although cumarine, fatty acids and alkaloids peroxides derivatives have also been isolated. Beside plants, many species of fungi and marine organisms produce metabolites containing a peroxide group. The peroxide function has been detected in different classes of natural compounds that are mentioned in Table I, based on the review published by Casteel (1992). The occurrence in vascular plant families according the literature published until 1999 is summarized by Table II.
Many biological activities were described for the peroxides. They show ichthyotoxic and antimicrobial activity, fungicide, anthelmintic and cytotoxic activity. At the moment, the most important activity exhibited by peroxides is the antimalarial activity (Vennerstrom, Easton, 1988; Rücker, 1994). The prevention and cure of malaria depends on a limited number of drugs. Resistance of the malaria parasites Plasmodium ssp. to drugs such as quinine (and more lately chloroquine) occurs with increasing frequency and emphasize the necessity to develop new agents for malaria chemotherapy (Kirby, 1996). Quinghaosu (artemisinin), a sesquiterpene isolated from Artemisia annua, is the best known plant derivative as an antimalarial drug after quinine (Klayman, 1985). Another sesquiterpene peroxide, named yingzhaosu, was isolated from Artabotrys uncinatus (Annonaceae) and also possesses a significant antimalarial activity. Both compounds contain an endoperoxid group, which is responsible for their activity (Klayman, 1985) and have opened a new chapter in the chemotherapy of malaria. The majority of drugs active against malaria are in fact derived from natural products or from structures suggested by natural products prototypes, but, as a source of novel drugs, plants remain largely understudied (Kirby, 1996). 
Herewith we report the screening for detection of peroxides in extracts from higher plants from the states of Rio Grande do Sul and Santa Catarina, Brazil, based on Huber \& Fröhlke's chromatographic test. The screening was developed to select promising plants for detailed investigation, aiming the isolation and structure elucidation of new peroxides.

TABLE I - Peroxide structures described in the literature considering the different classes of natural products

\begin{tabular}{lc}
\hline Class & Number of compounds \\
\hline Marine metabolites & 12 \\
Fatty acid derivatives & 39 \\
1,2-dioxancarboxilates & 11 \\
Others & \\
Terrestrial sources & 22 \\
Small molecules, hemiterpenes, & \\
$\quad$ and monoterpenes & 149 \\
Sesquiterpenes & 14 \\
Diterpenes & 5 \\
Triterpenes & 23 \\
Steroids & 9 \\
Others & \\
\hline
\end{tabular}

\section{MATERIAL AND METHODS}

Plants were collected from several localities in the aforementioned States, between December 1989 and February 1990, and identified by the authors N. Matzenbacher, M. Sobral, L. A. Mentz, and Sérgio A.L. or by the botanist Daniel Falkenberg (Universidade Federal de Santa Catarina). Voucher specimens were deposited at the ICN- Herbarium of the Instituto de Biociências da UFRGS, Porto Alegre, RS, Brazil.

Fresh plant material (10-20 g) was crushed and extracted with $\mathrm{CH}_{2} \mathrm{Cl}_{2}$ or $\mathrm{CHCl}_{3}(10-20 \mathrm{~mL})$ previously tested for peroxides. The extraction procedures were performed at the same day of the plant collection; in the case of distant places, the macerates were prepared at the field and concentrated at the laboratory. After maceration for 4$10 \mathrm{~h}$, the extracts were filtered and concentrated under reduced pressure until $1 \mathrm{~mL}$, at temperatures below $40{ }^{\circ} \mathrm{C}$.

The concentrated extracts were then chromatographed on silicagel $\mathrm{F}_{254}$ TLC plates, with $\mathrm{CH}_{2} \mathrm{Cl}_{2}$. In the case that peroxide-like spots appeared at the front, the TLC analysis was repeated using petroleum ether: AcOEt (9:1) as eluting solvent. After elution, the TLC was observed under UV light at 254 and $366 \mathrm{~nm}$. Afterwards
TABLE II - Number of species of the different plant families for which peroxides were reported (literature until 1999)

\begin{tabular}{|c|c|}
\hline Family & Number os species \\
\hline Annonaceae & 2 \\
\hline Apiaceae & 4 \\
\hline Araceae & 4 \\
\hline Aristolochiaceae & 3 \\
\hline Asclepiadaceae & 3 \\
\hline Asteraceae & 214 \\
\hline Celastraceae & 1 \\
\hline Chenopodiaceae & 4 \\
\hline Clusiaceae & 1 \\
\hline Cyperaceae & 1 \\
\hline Ericaceae & 2 \\
\hline Euphorbiaceae & 3 \\
\hline Fagaceae & 1 \\
\hline Hypericaceae & 3 \\
\hline Hippocastanaceae & 1 \\
\hline Hydrocharitaceae & 1 \\
\hline Lamiaceae & 9 \\
\hline Lauraceae & 1 \\
\hline Magnoliaceae & 3 \\
\hline Myrtaceae & 3 \\
\hline Pinaceae & 5 \\
\hline Pteridophyta & 2 \\
\hline Rosaceae & 2 \\
\hline Rutaceae & 2 \\
\hline Scrophulariaceae & 6 \\
\hline Solanaceae & 1 \\
\hline Valerianaceae & 2 \\
\hline Verbenaceae & 2 \\
\hline Zingiberaceae & 16 \\
\hline
\end{tabular}

the peroxides were detected by a specific reagent described by Huber and Fröhlke (1972). With this reagent, hydroperoxides develop blue spots immediately, and for endoperoxides the blue color appears after a few minutes.

\section{RESULTS AND DISCUSSION}

A total of 500 samples of 357 species were collected, including male and female individuals (some Baccharis species), and samples from different regions. The main target was Asteraceae, considering previous occurrence reports of peroxide compounds (Table II), and thus any found species was collected for the screening. Concomitantly, ca. the same number of species from other 
plant families were included to test the hypothesis of a restrictive distribution of peroxides. These samples of other families were collected randomly, and in the case of a positive result, more species from the same family were tested. Apart from the Asteraceae species, we tested 182 plants from 55 families, ca.1-3 species for each family, but in some cases a larger number were tested, as in the case of Myrtaceae (24 species), Euphorbiaceae (14), Verbenaceae (12) and Lamiaceae (11). Table III presents the 71 species tested which gave positive results and the plant material used for the extraction. Among the 175 species of Asteraceae tested for the presence of peroxides in leaves and blossoms, $40(30 \%)$ showed positive results. In the 182 plants classified in other families, $26(14 \%)$ showed positive results. These results indicated a higher occurrence of peroxides in the Asteraceae family and confirmed the literature data (Table II), but suggested that they can also be found frequently in other plant families, such as Myrtaceae and Verbenaceae.

Within the Asteraceae a higher rate of positive results were observed in genera belonging to the tribes Anthemideae and Senecioneae. Otherwise, in some tribes there were no samples with positive reaction, as in the case of Vernonieae (13 species tested), Cichorieae (3), Cynareae (2), Helenieae (2) (results not shown), or with a low rate, as in the case of tribes Inuleae (19 species tested, 1 positive result). The species which gave negative reaction with the peroxide reagent are not presented. The list of these plants can be obtained from the author to whom correspondence should be addressed.

From the plants listed on Table III, several were selected for detailed investigation, observing also factors as the abundance of the species and the foliar mass. From these works (Falkenberg, 1991; Marek, 1994; Heinzmann, 1996; Rücker et al., 1996) some new peroxides were isolated. Some of the isolated peroxides were also tested for antimalarial activity, semi-synthesized and derivatized (Rücker, 1994). The compound with most promising activity was 1 (bisabolene-1,4-endoperoxide $=1,4$ epidioxy-bisabolan-2,12-diene) (Figure 1), for which in vitro an $\mathrm{IC}_{50} 0.05$ was observed, in comparison with the value 0.005 for artemisinine as reference compound (Heinzmann, 1996; Rücker et al., 1997). Since the compound 1 was isolated from Heterothalamus psiadioides, H. alienus, Senecio selloi and Eupatorium rufescens (Heinzmann, 1996; Rücker et al., 1996; Rücker et al., 1996) it seems to have a wide occurrence, being first reported from Rudbeckia lasciniata (Bohlmann et al., 1978), and also from Ligularia speciosa (Bohlmann, Fritz, 1980), Chamaemelum fuscatum (Pascual et al. 1983) and Senecio desfontnei (Metwally, Dawidar, 1986). Two others bisabolan-type sesquiterpenes, zingiberene-3,6-aand zingiberene-3,6-b-endoperoxides ( 3 and 4 ) were isolated from S. selloi and E. rufescens and also showed antimalarial activity in vitro, but this activity was weaker than the activity of bisabolene-1,4-endoperoxide. S. selloi also contains two hydroperoxides (5 and $\mathbf{6}$ ), which were identified indirectly by isolation, identification and posterior photooxidation of $\alpha$-curcumene, their precursor in the plant (Figure 1). The detailed investigation of the $\mathrm{CH}_{2} \mathrm{Cl}_{2}$ extract of $S$. selloi also showed a greyish blue spot with the Huber's peroxide reagent. After isolation, this compound was identified as a triterpene ozonide (7), which contains a new 9-epi-cucurbitan skeleton (8) (Rücker et al., 1999).

The possible occurrence of peroxides in species of Myrtaceae, as suggested by our screening, was a subject of a detailed investigation. The substances giving positive reaction in the extracts from Eugenia hyemalis and Paramyrciaria glazioviana were isolated; the structure elucidation revealed these compounds to be the quinones 9, 10 (Figure 1) (Falkenberg, 1996). The high oxidation potential of this class is pointed as the reason for the positive reactions with the Huber's peroxide reagent (Kiefer, 1994).

\section{ACKNOWLEDGMENTS}

This work was supported by the German Institution Stifterverband für die Deutsche Wissenschaft (SV), the Brazilian agencies Fundação de Amparo a Pesquisa do Estado do Rio Grande do Sul (FAPERGS) and Conselho Nacional de Desenvolvimento Científico e Tecnológico (CNPq).

\section{RESUMO}

\section{Investigação de plantas brasileiras quanto à presen- ça de peróxidos}

Extratos clorofórmicos ou diclorometânicos de 357 espécies vegetais de ocorrência no sul do Brasil foram testados quanto à presença de peróxidos, através de cromatografia em camada delgada, utilizando o reagente de detecção de Huber \& Fröhlke. Das espécies testadas, 71 (20\%) apresentaram resultado positivo, a maioria delas $(56 \%)$ pertencentes à família Asteraceae. A maioria das espécies testadas pertencia a Asteraceae, mas outras 55 familias foram também testadas, abrangendo um total de 77 gêneros.

UNITERMOS: Peróxidos. Atividade antimalárica. Asteraceae. 
TABLE III - Extracts tested for the presence of peroxides which gave a positive reaction with the reagent described by Huber and Frölke, 1972. The signals $+\sim$ (weak positive reaction),,+++ and +++ were assigned considering the color intensity

ANACARDIACEAE ( 8 species tested)

Lithraea molleoides

Astronium balansae

Schinus lentiscifolius

Schinus molle

BORAGINACEAE (1 species tested)

Cordia curassavica

ASTERACEAE (175 species tested)

Tribe Anthemideae (6 species tested)

Artemisia alba

Artemisia cf. annua

Artemisia verlotorum

Chrysanthemum vulgare

Tribe Astereae (33 species tested)

Baccharis anomala (Guaiba)

Baccharis anomala (Porto Alegre)

Baccharis cf. artemisioides

Baccharis cylindrica (male; flowers)

Baccharis cylindrica (male; leaves)

Baccharis dracunculifolia

Baccharis ochracea

Baccharis pseudotenuifolia

Baccharis spicata

Grindelia buphtalmoides

Grindelia cf. pulchella

Heterothalamus alienus

Heterothalamus psiadioides

Hysterionica pinifolia

Tribe Eupatorieae (31 species tested)

Eupatorium ascendens

Eupatorium commersonii

Eupatorium intermedium

Eupatorium pedunculosum

Eupatorium serrulatum

Eupatorium spathulatum

Eupatorium tanacetifolium

Mikania laevigata

Mikania ternifolia

Symphyopappus casarettoi

Symphyopappus casarettoi (flowers)

Symphyopappus casarettoi (leaves)

Tribe Heliantheae (19 species tested)

Eclipta megapotamica

Galinsoga parviflora

Helianthus annuus

Verbesina subcordata

Tribe Inuleae (19 species tested)

Pterocaulon sp. 1

$+$

Tribe Mutisieae (13 species tested)

Gochnatia cordata

Gochnatia orbiculata

Mutisia sp.

Trichocline macrocephala

$+\sim$

$+\sim$

$+++$

$+\sim$

Tribe Senecioneae (9 species tested)

$++$

$+$

$+$

$++$

$+\sim$

$+\sim$

$+$

$+\sim$

$+\sim$

$++$

$+$

$++$

$+\sim$

$++$

$+\sim$

$+$

$+$

$+\sim$

$++$

$++$

$++$

$+$

$++$

$+\sim$

$++$

$+\sim$

$++$

$+++$
Erechthites hieraciifolia

Erechthites valerianifolia

Senecio bonariensis

Senecio crassiflorus

Senecio heterotrichus

Senecio heterotrichus

Senecio selloi

$++$

$++$

$+\sim$

$+$

$+$

$+\sim$

$+++$

EUPHORBIACEAE (14 species tested)

Croton gnaphalii

Euphorbia hirta

$+$

LAMIACEAE (10 species tested)

Hyptis mutabilis

MYRSINACEAE (3 species tested)

Myrsine umbellate

MYRTACEAE (24 species tested)

Blepharocalyx salicifolius

Eucalyptus calophylla

Eucalyptus camaldulensis

Eucalyptus citriodora

Eucalyptus globulus

Eucalyptus sideroxylon

Eucalyptus viminalis

Eugenia hyemalis

Eugenia hyemalis

Gomidesia palustris

Myrciaria cuspidata

Plinia trunciflora

$+$

$+\sim$

$+$

$++$

$+$

$++$

new leaves ++ old leaves + new leaves + old leaves + new leaves +

$++$

$+$

$++$

$+$

$+$

RUBIACEAE (11 species tested)

Cephalanthus glabratus

VERBENACEAE (12 species tested)

Aloysia gratissima

Aloysia sp. (Uruguaiana)

Verbena $\mathrm{cf}$. bonariensis

Verbena $\mathrm{cf}$. litoralis
$++$

$+$

$+$ 


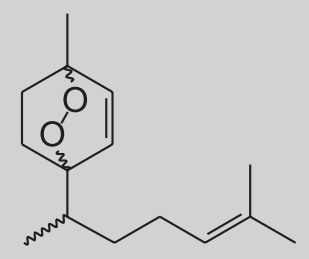

bisabolene-1,4-endoperoxide

1

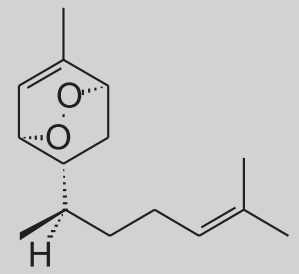

zing iberen e-3,6- $\alpha$-en doperoxide

3

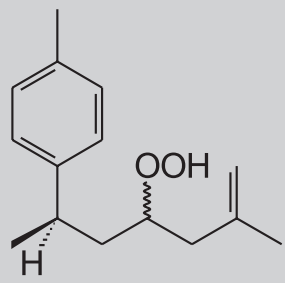

$\alpha$-curcum en e-9-hydroperoxide

5

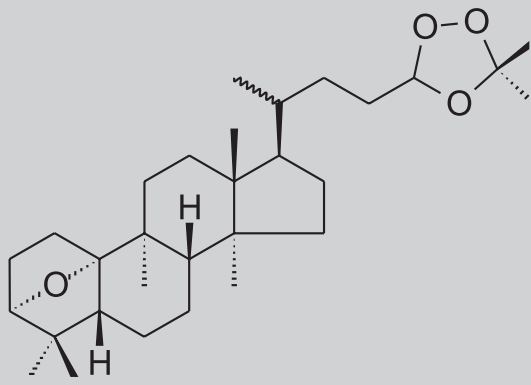

triterpene ozonide

7<smiles>O=C1C=CC(=O)C=C1</smiles>

p-benzoquinone

9

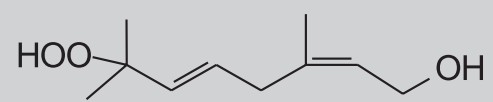

1 -hydroperoxy-5, 6-E-deh ydro6,7-deh ydron erol

2

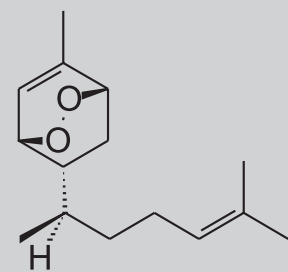

zing iberene-3,6- $\beta$-en doperoxide 4

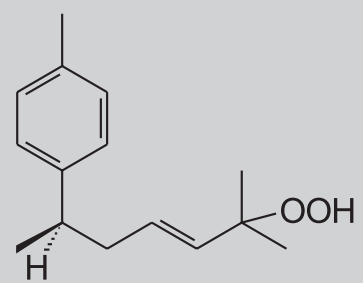

$\alpha$-curcum en e-11-hydroperoxide

6

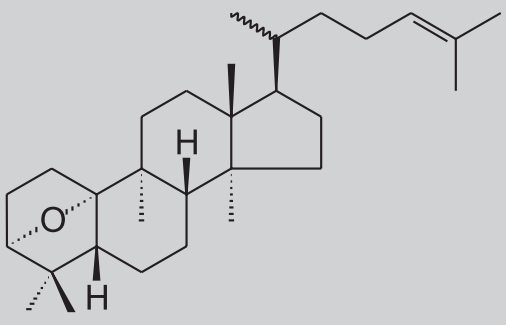

ozonide precursor

8

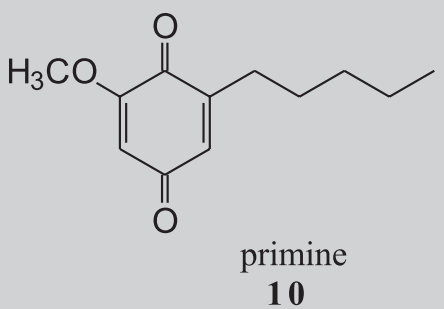

FIGURE 1 - Compounds isolated from Heterothalamus alienus (1, 2, 3 and 4), H. psiadioides (1), Eupatorium rufescens (1,3 and 4), Eugenia hyemalis and Paramyrciaria glazioviana. 


\section{REFERENCES}

BOHLMAN, F., FRITZ, U. Isofukinone, an eremophilane from Ligularia speciosa. Phytochemistry, v.19, p. 24712472, 1980.

BOHLMAN, F., JAKUPOVIC, J., ZDERO, C. Neue Norsesquiterpene aus Rudbeckia lasciniata und Senecio paludoaffinis. Phytochemistry, v.17, p. 2034-2436, 1978.

CASTEEL, D. A. Peroxy natural products. Natural Product Reports, v. 24, p. 289-312, 1992.

FALKENBERG, M. B. Chinone und andere Inhaltsstoffe aus Eugenia hiemalys Camb. und Paramyrciaria glazioviana (Kiaerskou) Sobral. Boon, 1996. 84p. [PhD Thesis. Universität Bonn].

GESSNER, O. Die Gift-und Arzneipflanzen von Mitteleuropa. Heidelberg: Carl Winter-Universitätsverlag, 1953.933 p.

HEINZMANN, B. M. Inhaltsstoffe aus Senecio selloi Spreng. de Candolle. Boon, 1996. 149p. [PhD Thesis. Universität Bonn].

HOPE, H. A. Drogenkunde. 7 ed. Hamburg: Cram, de Gruyter \& Co, 1958. $1231 \mathrm{p}$.

HUBER, H., FRÖHLKE, E. A new spray-reagent for the detection and quantitative estimation of peroxides. Chromatographia, v. 5, p. 256-257, 1972

KIEFER, A. Untersuchungen zur quantitativen bestimmung von peroxiden am beispiel der schafgarbe. Boon, 1994. 136p. [PhD Thesis. Universität Bonn].

KIRBY, G. C. Medicinal plants and the control of protozoan disease, with particular reference to malaria. Trans. $R$. Soc. Trop. Med.Hyg., v. 90, p. 605-609, 1996.

KLAYMAN, D.L. Qinghaosu (Artemisinin) - An antimalarial drug from China. Science, v. 228, p.1049$1055,1985$.

MAREK, A. M. E. Peroxide und andere Inhaltsstoffe aus Heterothalamus-Arten und malariawirksame Abwandlungsprodukte der Peroxide. Boon, 1994. 202p. [PhD Thesis. Universität Bonn].
METWALLY, M. A., DAWIDAR, A. A. Constituents of Senecio desfontanei. Pharmazie, v. 41, p. 552-553, 1986.

PASCUAL, J., DE CABALlERO, E., ANAYA, J., GONZALEZ, M. S. Four aliphatic esters of Chamamelium fuscatum essential oil. Phytochemistry, v. 22, p. 1757-1759, 1983.

RÜCKER, G. Pharmazeutisch wichtige Naturstoffe im Blickpunkt. Pharmazie in unserer Zeit, v. 23, p. 223-225, 1994.

RÜCKER, G., BREITMAIER, E., MANNS, D., MAIER, W., MAREK, A.,HEINZMANN, B., HEIDEN, K., SEGGEWIES, S. Antimalarial activity of 1,4-epidioxybisabola-2,12-diene derivatives. Arch. Pharm. Med. Chem., v. 330, p.12-16, 1997.

RÜCKER, G., SCHENKEL, E. P., MANNS, D., FALKENBERG, M., MAREK, A., Peroxides and other constituents from Heterothalamus alienus. Phytochemistry, v. 41, p. 297-300, 1995.

RÜCKER, G., SCHENKEL, E.P., MANNS, D., MAYER, R., HAUSEN, B.M., HEIDEN, K. Allergenic Sesquiterpene lactones from Eupatorium cannabinum $\mathrm{L}$. and Kaunia rufescens. Nat. Toxins, v. 5, p. 223-227, 1997.

RÜCKER, G., SCHENKEL, E.P., MANNS, D., MAYER, R., HEIDEN, K., HEINZMANN, B.M. Sesquiterpene Peroxides from Senecio selloi and Eupatorium rufescens. Planta Med., v. 62, p. 565-566, 1996.

RÜCKER, G., MANNS, D., SCHENKEL, E. P., HARTMANN, R., HEINZMANN, B. M. Sesquiterpene peroxides from Senecio selloi. Phytochemistry, v. 52, p. 1587-1591, 1999.

VENNERSTROM, J. L.; EASTON, J. W. Oxidants, oxidant drugs and malaria. J. Med. Chem., v.31, p. 1269-1277, 1988.

Recebido para publicação em 20 de dezembro de 2001. 